\title{
Primary Epstein-Barr virus infection in early childhood
}

\author{
S KRABBE, J HESSE, AND P ULDALL \\ Children's Hospital, Fuglebakken, University Department of Paediatrics, and Institute of Medical \\ Microbiology, University of Copenhagen, Denmark
}

SUMMARY In a prospective study 43 consecutive children in hospital, aged between 6 months and 7 years and displaying at least one of the clinical signs of infectious mononucleosis (IM), were investigated for Epstein-Barr (EB) virus-specific IgM antibodies by an indirect immunofluorescence test. On this basis EB virus infection was considered confirmed in 8 patients, each of whom had IgM antibodies in the initial serum sample. In one additional patient, IgM antibodies were only detected in a second sample. The IgM antibodies disappeared within 3-11 weeks. Assessment of IgG antibodies had no diagnostic value in the acute phase of IM. Clinically the 3 youngest children, about 1 year of age, were diagnosed as having pneumonia or hepatitis, the 5 other consecutive patients as having IM. Hepatosplenomegaly was fairly frequently associated with IM, while sore throat, lymphadenopathy, and rash were often signs of other diseases. Only the oldest child had heterophil antibodies. Atypical lymphocytes $(>10 \%)$ were present in 4 of the 9 IM cases and were seen in children with other diseases as well. Our data stress the importance of measuring EB virusspecific IgM antibodies in order to diagnose IM in early childhood.

It is now well known that the Epstein-Barr (EB) virus is the cause of infectious mononucleosis (IM). ${ }^{1}$ During the acute phase of the disease EB virusspecific IgG antibodies rise and reach maximum levels so early ${ }^{2}$ that it is hardly possible to use an increase in IgG titre in diagnosis. However, a fluorescence method for determining EB virusspecific IgM antibodies, developed by Schmitz and Scherer, ${ }^{3}$ enables an accurate and specific diagnosis of primary EB virus infections to be made. This technique is of particular value in early childhood infections, as atypical cases of primary EB virus infection are frequent with asymptomatic infections or mild illness of the upper respiratory tract ${ }^{4}$ and lack of heterophil antibodies. ${ }^{2}$ Only a few studies using EB virus-specific IgM as the diagnostic tool in childhood EB viral infections have been reported, and they dealt with clinically or serologically selected groups of patients ${ }^{3-6}$ or were retrospective. ${ }^{7}$

This prospective study comprised pre-school children admitted to hospital, displaying one or more of the classical signs or symptoms of IM. The aim was to describe their clinical, haematological, and serological features, with diagnosis based on the presence of specific IgM antibodies to EB virus.

\section{Materials and methods}

The study took place in a children's hospital in an urban area. Children in hospital aged between 6 months and 7 years were selected consecutively during a 9-month period if one of the following was present: nonbacterial pharyngitis or tonsillitis (sore throat), lymphadenopathy, hepatosplenomegaly, rash of unknown aetiology, a blood count with more than $10 \%$ atypical lymphocytes, and thrombocytopenia. All patients had throat cultures and complete blood counts. Samples of sera were obtained as early as possible and tested for heterophil antibodies, specific IgG and IgM antibodies to EB virus capsid antigen (EB-VCA), and specific IgG antibodies to cytomegalovirus (CMV). These analyses were repeated during convalescence if at all possible. One additional patient, diagnosed later, was included in the study because of a differing serology.

Antibodies to EB-VCA were detected by indirect immunofluorescence tests. ${ }^{10}$ The Burkitt cell line P3HR-1 was the antigen source. The FITC-conjugates were rabbit antihuman IgG and rabbit antihuman IgM (DAKO-immunoglobulins, Copenhagen). IgG antibodies were measured as described by Henle et al. ${ }^{2}$ 
IgM antibodies were detected by the method described by Nikoskelainen and Hänninen, ${ }^{8}$ modified according to Horwitz ${ }^{20}$ in order to give access to the large IgM molecules. After acetone fixation cell smears were rinsed twice in a $1.2 \%$ (by vol) solution of a nonionic detergent (Nonidet P40, Shell). To find out the specificity of the test, all positive sera were tested for presence of rheumatoid factor ${ }^{9}$ by Hyland's latex agglutination slide test (Latex-RFReagenz, Behringswerke AG).

To determine the presence of heterophil antibodies, sera were tested with the sheep red cell agglutination test (Paul-Bunnell) ${ }^{11}$ and with the horse cell slide test on absorbed sera (Monospot, Ortho Diagnostics).

To test for antibodies to CMV, a complement fixation assay was used, modified as a microtechnique. $^{12}$

\section{Results}

A total of 44 children were studied. Eight $(19 \%)$ out of 43, and also the patient included later (Case 9), had specific IgM antibodies to EB-VCA in at least one sample.

Patients with IgM antibodies to EB virus. The main clinical and haematological findings of the 9 IgMpositive children are given in Table 1 . In general, symptoms and signs of IM were less pronounced in the 3 youngest children. All 9 patients had febrile episodes, 2 had asymptomatic thrombocytopenia. The levels of IgM antibodies and their relationship to the onset of disease are given in Fig. 1. Six of the consecutive patients had more than one serum sample taken, and each of them showed maximum IgM titre in the first specimen. In the additional case (Case 9) no IgM antibodies were demonstrable in the first sample, but a second one taken 2 days later showed seroconversion. The peak titres ranged widely-from 1280 to 40 .

Six cases were followed until they were sero-

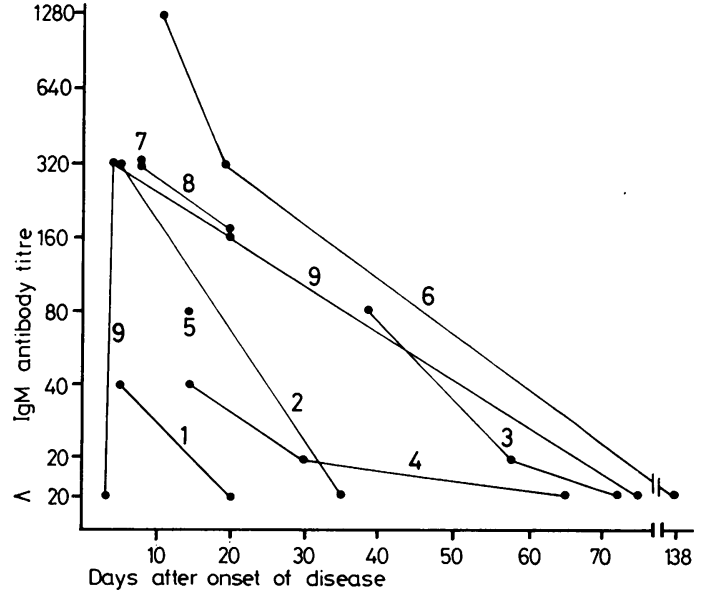

Fig. 1 IgM antibody titres to EB virus capsid antigen in relation to onset of disease in 9 children with infectious mononucleosis. The figures refer to individual cases.

negative, which occurred between days 20 and 75, except for Case 6, whose third sample was taken as late as $4 \frac{1}{2}$ months after clinical onset. Seroconversion was not observed in Case 8 but no sample was obtained later than day 20.

The levels of IgG antibodies and their relationship to the onset of illness are shown in Fig. 2. The initial titres of the 8 seropositive patients were within the range for healthy adults. ${ }^{13}$ In one patient (Case 6) IgG antibodies were undetectable in the first sample. All second samples (7 patients) had unchanged titres, whereas third samples (4 patients) showed a moderate rise in titre, or, in one patient, seroconversion (Case 6). A decline in titre was not observed.

In 8 cases no heterophil antibodies were detected, either with the Paul-Bunnell or the monospot test. The oldest child, aged 7, had heterophil antibodies with both tests. None had serological evidence of an acute CMV infection.

Table 1 Clinical manifestations and white blood cell counts in patients with specific IgM antibodies to EB virus

\begin{tabular}{|c|c|c|c|c|c|c|c|c|c|c|c|}
\hline Case & $\begin{array}{c}\text { Age } \\
\text { (months) }\end{array}$ & Sex & $\begin{array}{l}\text { Sore } \\
\text { throat }\end{array}$ & $\begin{array}{l}\text { Lymph- } \\
\text { adenopathy }\end{array}$ & $\begin{array}{l}\text { Enlarged } \\
\text { liver or } \\
\text { spleen }\end{array}$ & Rash & $\begin{array}{l}\text { Palpebral } \\
\text { oedem. }\end{array}$ & $\begin{array}{l}\text { Leucocytes } \\
\left(\times 10^{9} / l\right)\end{array}$ & $\begin{array}{l}\text { Lymphocytes } \\
(\%)\end{array}$ & $\begin{array}{l}\text { Atypical } \\
\text { lymphocytes } \\
(\%)\end{array}$ & $\begin{array}{l}\text { Clinical } \\
\text { diagnosis }\end{array}$ \\
\hline $\begin{array}{l}1 \\
2 \\
3 \\
4 \\
5 \\
6 \\
7 \\
8 \\
8\end{array}$ & $\begin{array}{l}10 \\
12 \\
14 \\
25 \\
34 \\
44 \\
53 \\
84 \\
30\end{array}$ & $\begin{array}{l}\mathbf{F} \\
\mathbf{M} \\
\mathbf{F} \\
\mathbf{F} \\
\mathbf{M} \\
\mathbf{M} \\
\mathbf{M} \\
\mathbf{M} \\
\mathbf{F}\end{array}$ & $\begin{array}{l}\text { Slight } \\
\text { Slight } \\
\text { Slight } \\
\text { Marked } \\
\text { Marked } \\
\text { Slight } \\
\text { Marked } \\
\text { Marked } \\
\text { Marked }\end{array}$ & $\begin{array}{l}\text { Slight } \\
\text { Slight } \\
\text { Slight } \\
\text { Marked } \\
\text { Marked } \\
\text { Marked } \\
\text { Marked } \\
\text { Marked } \\
\text { Marked }\end{array}$ & $\begin{array}{l}\text { Slight } \\
\overline{\text { Marked }} \\
\text { Slight } \\
\overline{\text { Marked }} \\
\text { Marked } \\
\text { Slight } \\
\text { Marked }\end{array}$ & $\begin{array}{l}\overline{\text { Present }} \\
= \\
= \\
= \\
= \\
=\end{array}$ & $\begin{array}{l}\bar{z} \\
\text { Present } \\
= \\
= \\
\overline{-} \\
\text { Present }\end{array}$ & $\begin{array}{r}9 \cdot 2 \\
13 \cdot 0 \\
11 \cdot 7 \\
7.7 \\
13 \cdot 7 \\
11 \cdot 1 \\
19 \cdot 9 \\
23 \cdot 4 \\
12 \cdot 4\end{array}$ & $\begin{array}{l}79 \\
85 \\
70 \\
27 \\
33 \\
75^{*} \\
81^{*} \\
65^{*} \\
69\end{array}$ & $\begin{array}{r}\frac{1}{18} \\
20 \\
\frac{-}{13} \\
7 \\
46\end{array}$ & $\begin{array}{l}\text { Pneumonia } \\
\text { Pneumonia } \\
\text { Infectious hepatitis } \\
\text { Suspected IM } \\
\text { Suspected IM } \\
\text { IM } \\
\text { IM } \\
\text { IM } \\
\text { IM }\end{array}$ \\
\hline
\end{tabular}

*Raised lymphocyte count for age. 


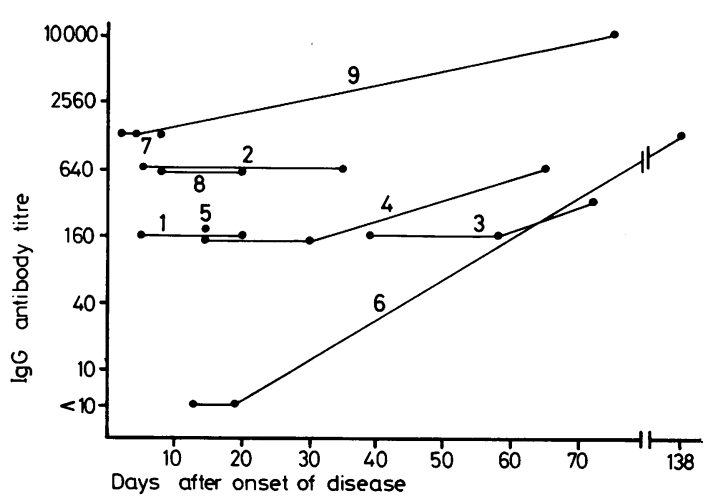

Fig. 2 IgG antibody titres to EB virus capsid antigen in relation to onset of disease in 9 children with infectious mononucleosis. The figures refer to individual cases.

Patients without IgM antibodies to EB virus. Table 2 shows the main clinical findings, and the cases with atypical lymphocytes $(>10 \%)$ for the 35 patients without IgM antibodies and the 8 patients with IgM antibodies. Nonbacterial sore throat and lymphadenopathy were present in many of the patients with diseases other than IM. Hepatosplenomegaly was fairly frequent in IM. Palpebral oedema was present in both groups, whereas a nonspecific rash was present, with only rare exceptions, in the group without IgM antibodies. More than $10 \%$ atypical lymphocytes, present in nearly half the IM patients, was seen too in children with other diseases.

One patient showed a false-positive reaction for IgM antibodies to EB virus: a titre of 40 in two successive samples was reduced to $<20$ by absorption with aggregated gammaglobulin. 10 children had IgG antibodies to EB virus. Among the 25 IgG-negative cases, no seroconversion was observed. None of the patients with diseases other than IM had heterophil antibodies, but one child showed a significant rise in IgG antibodies to CMV ( $<8$ to 16$)$.

Table 2 Clinical features and atypical lymphocytes in 43 children suspected to have infectious mononucleosis

\begin{tabular}{lll}
\hline & $\begin{array}{l}\text { Without EB virus } \\
\text { specific IgM } \\
\text { antibodies } \\
(n=35)\end{array}$ & $\begin{array}{l}\text { With EB virus } \\
\text { specific IgM } \\
\text { antibodies } \\
(n=8)\end{array}$ \\
\hline Nonbacterial & & \\
sore throat & 22 & 8 \\
Lymphadenopathy & 19 & 8 \\
Enlarged liver/spleen & 8 & 6 \\
Rash (unknown aetiology) & 15 & 1 \\
Palpebral oedema & 2 & 1 \\
$>10 \%$ atypical & 4 & 3 \\
lymphocytes & & \\
\hline
\end{tabular}

\section{Discussion}

Typical examples of IM may be seen in pre-school children, ${ }^{14}$ but in other studies ${ }^{4-15}$ IM has been described as presenting in an atypical illness in children.

In this prospective study of patients in hospital the 3 youngest children initially gave no clinical suspicion of IM, although fulfilling criteria for inclusion in the study. (Sore throat and a variable lymphadenopathy were present in all patients with IgM antibodies, but these findings were also common among 35 children with other diseases). Looking at all 43 consecutive patients suspected of having IM, it can be seen that primary EB virus infection should be considered if hepatosplenomegaly or palpebral oedema is present (Table 2).

During a 9 months' period we were able to find only 8 children with IM at a children's hospital serving a large community. This fact supports the general view that primary EB virus infection is generally asymptomatic or mild in early childhood.

As might have been expected none of the children less than 5 years had heterophil antibodies. ${ }^{17}$ More importantly, atypical lymphocytes were present rather spasmodically. Traditionally, atypical lymphocytes are essential for the diagnosis of IM, ${ }^{16}$ especially in the absence of heterophil antibodies. However, the existence of such lymphocytes in other viral infections is well known. ${ }^{18}$ Our findings suggest that demonstration of these cells is not essential, but if present they should raise suspicion of IM (Table 2). Unlike heterophil antibodies, the absence of atypical lymphocytes was unrelated to age.

Demonstration of IgM antibodies to EB virus by the IF method is a very reliable criterion for primary EB virus infection, ${ }^{2}$ being a sensitive and specific test, ${ }^{19}$ although cross-reaction with CMV specific antibodies has been reported. ${ }^{3}$ Our finding of IgM seropositivity in all first serum samples taken at least 5 days after clinical onset is in accordance with observations in adult patients. ${ }^{2} 5$ Case 9 illustrates the fact that an early sample may fail to show IgM antibodies and such cases require a second sample a f zw days later, if clinically suspicious.

The level of IgM antibodies changed rapidly: Case 9 seroconverted to a high titre in 2 days, and all second samples showed a decrease in titre. Together with a considerable variation in peak titres, this emphasises the transient nature of EB virus-specific IgM antibodies in early childhood.

The earliest seroconversion in our study was recorded 3 weeks after onset of disease. Thus it is possible that patients with a primary EB virus infection and a late first serum sample may be lost 
among the IgM-negative but IgG-positive cases. Only 2 such children were suspected in this series, but their subsequent course disclosed infection of other origin.

Case 6 was unique in having no IgG antibodies as late as 3 weeks after onset of illness, and only in this child were repeated measurements of IgG antibodies of diagnostic value. Four of our 9 patients had blood samples taken later than 2 months after onset, and each showed an increase in IgG titre. This is at variance with Henle et al., ${ }^{2}$ but in accordance with Evans et al., ${ }^{19}$ who described a slight peak geometric mean IgG titre at 3 months.

The 3 youngest children had actually been discharged from hospital before being diagnosed as having IM, stressing the importance of measuring EB virus-specific IgM antibodies to diagnose IM in early childhood.

We thank Dr Allan Hornsleth, Institute of Medical Microbiology, Copenhagen, for performing the CMV complement fixation assay.

\section{References}

1 Henle W, Henle G. Epstein-Barr virus and infectious mononucleosis. $N$ Engl J Med 1973; 288: 263-4.

2 Henle G, Henle W, Horwitz C A. Epstein-Barr virusspecific diagnostic tests in infectious mononucleosis. Hum Pathol 1974; 5: 551-65.

3 Schmitz H, Scherer M. IgM antibodies to Epstein-Barr virus in infectious mononucleosis. Arch Gesamte Virusforsch 1972; 37: 332-9.

4 Henle G, Henle W. Observations on childhood infections with the Epstein-Barr virus. J Infect Dis 1970; 121: 303-10.

5 Nikoskelainen J, Leikola J, Klemola E. IgM antibodies specific for Epstein-Barr virus in infectious mononucleosis without heterophil antibodies. $B r$ Med J 1974; iv: 72-5.

- Ginsburg C M, Henle W, Henle G, Horwitz C A. Infectious mononucleosis in children. Evaluation of EpsteinBarr virus-specific serological data. JAMA 1977; 237: 781-5.

7 Sumaya C V. Primary Epstein-Barr virus infections in children. Pediatrics 1977; 59: 16-21.
8 Nikoskelainen J, Hänninen P. Antibody response to Epstein-Barr virus in infectious mononucleosis. Infect Immun 1975; 11 : 42-51.

9 Fraser K B, Shirodaria P V, Stanford C F. Letter: Fluorescent staining and human IgM. Br Med J 1971; iii: 707.

10 Henle G, Henle W. Immunofluorescence in cells derived from Burkitt's lymphoma. J Bacteriol 1966; 91 : 1248-56.

11 Davidsohn I, Lee C L. Serologic diagnosis of infectious mononucleosis. A comparative study of five tests. Am J Clin Pathol 1964; 41 : 115-25.

12 Sever S L. Application of a microtechnique to viral serological investigations. J Immunol 1962; 88: 320-9.

13 Hesse J, Levine P H, Ebbesen P, Conelly R R, Mordhorst C H. A case control study on immunity to two EpsteinBarr virus-associated antigens and to herpes simplex virus and adenovirus in a population-based group of patients with Hodgkin's disease in Denmark, 1971-73. Int $J$ Cancer 1977; 19: 49-58.

14 Starling K A, Fernbach D J. Letter: Infectious mononucleosis in the preschool child. JAMA 1968; 203: 810.

15 Tischendorf P, Shramek G J, Balagtas R C, et al. Development and persistence of immunity to Epstein-Barr virus in man. J Infect Dis 1970; 122: 401-9.

16 Tamir D, Blenderly A, Levy J, Ben-Porath E, Vonsover A. Infectious mononucleosis and Epstein-Barr virus in childhood. Pediatrics 1974; 53: 330-5.

17 Vahlquist B, Ekelund H, Tveterås E. Infectious mononucleosis and pseudomononucleosis in childhood. Acta Paediatr Scand 1958; 47: 120-31.

18 Wood T A, Frenkel E P. The atypical lymphocyte. Am J Med 1967; 42: 923-36.

19 Evans A S, Niederman J C, Cenabre L C, West B, Richards V A. A prospective evaluation of heterophil and Epstein-Barr virus-specific IgM antibody tests in clinical and subclinical infectious mononucleosis. Specificity and sensitivity of the tests and persistence of antibody. $J$ Infect Dis 1975; 132: 546-54.

20 Horwitz C A, Henle W, Henle G, Schmitz H. Clinical evaluation of patients with infectious mononucleosis and development of antibodies to the $\mathrm{R}$ component of the Epstein-Barr virus-induced early antigen complex. Am J Med 1975; 58: 330-8.

Correspondence to Dr S Krabbe, Children's Department, Frederiksborg Amts Central Hospital, DK3400 Hillerød, Denmark.

Received 23 October 1979. 